\title{
Ruokinnan vaikutus maidon koostumukseen ja ravintoarvoon ${ }^{1}$ )
}

\author{
VAPPU KosSILA \\ Maatalouden tutkimuskeskus, Kotieläinhoidon tutkimuslaitos, Tikkurila
}

Saapunut 3.5.1974

\section{Nutritional factors and composition of milk $^{\mathbf{1}}$ )}

VAPPU KossILA

Agricultural Research Centre, Department of Animal Husbandry

\begin{abstract}
Composition of milk is influenced among others by age, physiological state, health, breed, hormonal functions and level of milk yield of the cow. When these factors are kept constant the effects of chemical constituents and physical form of feeds on the composition of milk can be observed. In practical dairy cattle feeding it is relatively easy to produce changes in the contents of fat, fat-soluble vitamins and some trace elements, notably iodine, of milk. Also, it is possible to modify the fatty acid composition of milk fat in a direction which is believed to be desirable from the point of view of human nutrition. On the other hand, the content of proteins in cow's milk can hardly be influenced assuming that the cow has received such amounts of energy and crude protein as meet her nutritional requirements.

The lactose content of cow's milk cannot be influenced by feeding unless the level of glucose in the cow's blood is below normal. If water-soluble vitamins are given to the cow, only a very small part of these are transferred into the milk. The same is true with regard to most minerals and trace elements.
\end{abstract}

Maidon koostumukseen vaikuttavat ruokintatekijöiden ohella mm. lehmän ikä ja fysiologinen tila, tuotetun maidon määrä, tuotantokauden vaihe, ympäristön lämpötila, terveydentila, rotu ja hormonaalinen kokoonpano. Ruokintatekijöiden vaikutusta maidon koostumukseen voidaan tarkastella pitämällä muiden tekijöiden vaikutukset vakiona.

1) Esitelmä, jonka tohtori Kossila piti Suomen Maataloustieteellisen Seuran symposiumissa 29.1.1974.

1) Lecture given at the symposium of the Scientific Agricultural Society of Finland in Helsinki on January 29, 1974. 
Maito koostuu:

- vedestä

- rasvasta

- valkuaisaineista ja muista typellisistä aineista

- maitosokerista (laktoosi)

- kivennäisaineista (pääkivennäiset, hivenaineet)

- vitamiineista (rasva- ja vesiliukoiset)

- muista aineista kuten solunkappaleista, entsyymeistä jne.

Rehun hajaantuessa ruoansulatusprosessissa ja hajaantumistuotteiden imeytyessä ruoansulatuskanavasța verenkiertoon, joutuvat rehusta peräisin olevat ainekset joko sellaisenaan țai elimisțössä modifioituina maitorauhaseen. Täällä niistä rakennetaan maidon aineosia. Jos jostakin esiaineesta on niukkuutta korvataan se toisella esiaineella mikäli mahdollista. Muussa tapauksessa kyseessä olevaa ainetta komponenttinaan tarvitsevan maidon aineosan määrä alentuu tai maidoneritys vähenee.

\section{Maidon rasva}

Ruokinnan vaikutusta maidon rasvapitoisuuteen ja rasvan koostumukseen on tutkittu ehkä eniten. Pääosa maidon rasvasta (98\%) on triglyseridejä. Maidon rasvan esiaineina veriseerumissa ovat: etikkahappo ja $\beta$-oksivoihappo, jotka ovat peräisin pötsissä bakteerien toimesta syntyneistä etikkahapoista ja voihaposta; low-density $\beta$-lipoproteiinien ja chylomikronien triglyseridit, jotka ovat peräisin ohutsuolesta imunesteeseen tai vereen imeytyneistä $C_{12}-C_{18}$ rasvahapoista; glukoosi, joța syntetisoidaan lehmän elimistössä.

Etikkahaposta ja $\beta$-oksivoihaposta syntetisoidaan maitorauhasessa maitorasvan $\mathrm{C}_{4}-\mathrm{C}_{16}$ rasvahapot, joiden osuus maitorasvan rasvahappokoostumuksesta on noin 58-62 mooliprosenttia. Jos lehmän ruokintaa mutetaan siten että etikka- ja voihappotuotanto pötsissä alenee, niin tämä johtaa maitorasvan $C_{4}-C_{16}$ rasvahappojen määrän ja rasvaprosentin alenemiseen. Etikkahappotuotannon muutosten vaikutus on kvantitatiivisesti tärkeämpi kuin voihappotuotannon tässä mielessä.

Pötsin haihtuvien rasvahappojen välisiä suhteita voidaan muuttaa ruokinnallisin keinoin antamalla lehmälle esimerkiksi vähemmän heiniä ja enemmän väkirehua țai pelletöimällä tai jauhamalla korsirehu, jolloin pötsin etikkahappotuotannon suhde propionihappotuotantoon pienenee ja maidon rasvaprosentti alenee. Pötsin propionihappotuotantoa voidaan taas edistää antamalla lehmälle esimerkiksi maissihiutaleita tai kuumennettua viljaa tavallisten jauhojen sijasta. Kovin runsas viljaruokinta johtaa kuitenkin liialliseen maitohappomuodostukseen, pötsin $\mathrm{pH}: \mathrm{n}$ alenemiseen ja ruokahaluttomuuteen, joiden ilmiöiden seurauksena maidon rasvapitoisuus alenee.

Low-density $\beta$-lipoproteinien ja chylomikronien sisältämät triglyseridit tuovat maitorauhaseen mukaan sekä $\mathrm{C}_{12}-\mathrm{C}_{16}$, mutta erikoisesti $\mathrm{C}_{18}$ rasvahappoja. Ilmeisesți suurin osa triglyserideistä hajotetaan entsymaattisesti maito- 
rauhasessa glyseroliksi ja vapaiksi rasvahapoiksi. Nämä muodostavat maitorauhasessa osan ns. rasvahappo-glyserolipoolista. Maitorauhasessa syntetisoidaan mainitun poolin aineksia hyväksikäyttäen maidon triglyseridejä. Veriseerumin triglyseridit palvelevat erityisesti maitorasvan korkeimpien rasvahappojen, kuten $\mathrm{C}_{18}$-happojen esiaineena. Tutkimuksissa on todettu, että maitorauhanen ottaa verestä niin paljon triglyseridimuodossa olevia rasvahappoja, että niiden määrä riittäisi jo yksinään maitorasvan muodostukseen. Kuitenkin pitempiketjuisten, kuten $\mathrm{C}_{18}$-rasvahappojen, määrä vaihtelee maitorasvassa $30-50 \%$ riippuen ruokinnasta. Osa $\mathrm{C}_{18}$-rasvahapoista on monityydyttämättömiä ja osa tyydytettyjä. Tutkimuksissa on todettu että antamalla lehmälle monityydyttämätț̈miä rasvoja tai näitä runsaasti sisältäviä rehuja maidon $\mathrm{C}_{18}$-tyydyttämättömien (varsinkin $\mathrm{C}_{18}:{ }_{1}$ ) rasvahappojen pitoisuudet lisääntyvät. Samalla maidon rasvaprosentti alenee koska tyydyttämättömät rasvahapot suosivat propionihapposynteesiä pötsissä. Osa tyydyttämättömistä rasvahapoista hydrautuu pötsissä, osa imeytyy sellaisenaan ohutsuolesța.

Maidon triglyseridien glyseroliosa on peräisin a) joko siitä glyserolista, jota tulee maitorauhaseen plasman mukana tuoduista triglyserideistä tai b) veriseerumin glukoosista, josta lohkaistaan puolet glyserolimolekyylin muodostukseen ja josta toinen puoli käytetään maidon synteesiin tarvittavan energian lähteenä.

Maidon rasvaprosenttia voidaan nosțaa syöttämällä lehmälle runsaasti energiaa, sopivia rasvoja ja kuitua oikeissa suhteissa tai antamalla lehmälle etikkahappoa tai etikkahapon suoloja.

Rasvaprosenttia voidaan alentaa syöttämällä lehmälle runsaasti väkirehua, siirtämällä sisäruokinnasta laitumelle, antamalla väkirehua korsirehun kustannuksella, syöttämällä hienoksi jauhettua heinää pitkän sijasta, tai syöttämällä pelletoitua väkirehua jauhon sijasta.

Ravintona runsasrasvainen maito on energiarikkaampaa kuin vähärasvainen maito. Mitä tulee maidon sisältämien rasvahappojen terveellisyyteen ollaan tästä eri mieltä.

\section{Maidon valkuainen}

Pääpiirteittäin tarkasteltuna maidon valkuainen koostuu: kaseiinista $(\alpha-\mathrm{ja}$ $\beta$-kaseiini sekä kappa-kaseiini), laktalbumiinista ( $\alpha$-laktalbumiini, $\beta$-laktoglobuliini, seerumi-albumiini) ja laktoglobuliinista (immuniglobuliinit). Lisäksi maidossa on jonkinverran ei-proteiinityppeä (NPN-fraktio), jonka määrä vaihtelee $4-6 \%$ kokonaistypen määrästä. $\alpha$ - ja $\beta$-kaseniinit muodostavat pääosan maidon valkuaisesta. Nämä sekä $\alpha$-laktalbumiini ja $\beta$-laktoglobuliini muodostuvat maitorauhasessa verestä otetuista aminohapoista. Seerumialbumiini ja immuuniglobuliini tulevat maitoon verestä sellaisinaan ilman että ne käyvät lävitse muodonmuutosta.

Maidon valkuaispitoisuus vaihtelee huomattavasti vähemmän kuin rasvapitoisuus ja valkuaispitoisuuteen ei voidakaan ruokinnalla vaikuttaa yhtä paljon kuin rasvapitosuuteen. Ruokinnalla ei myöskään voida vaikuttaa mai- 
don valkuaisten ketjun aminohappokoostumukseen koska tällä on geneettisesti määrätty struktuuri. Eri valkuaisfraktioiden välisiä suhteita voidaan ruokinnallisin keinoin muuttaa jonkinverran. Tutkimuksissa on todettu että maitorauhanen ottaa veriseerumista niin paljon aminohappoja että nämä riittäisivät muodostamaan kokonaan maidon valkuaisen.

Maitovalkuainen sisältää runsaasti välttämättömiä aminohappoja. Näistä metioniinin ja fenylalaniinin määrät lehmän veressä ovat hyvin alhaiset, ja nämä kaksi aminohappoa voivatkin esiintyä rajoittavina tekijöinä maidon valkuaisainesynteesissä. Edelleen on havaittu, että jos lehmän raakavalkuaisțarpeesta tyydytetään huomattava osa ei-proteiini-typellä kuten urealla, saattaa tulla puutosta myös histidiinistä ja leusiinista.

Kun maitorauhanen valmistaa aminohapoista valkuaista, niin yhden maitolitran muodostamiseen tarvitaan $30 \mathrm{~g}$ aminohappoja ja $7 \mathrm{~g}$ glukoosia. Tämä glukoosi hapettuu ja siitä saatu energia käytetään valkuaismolekyylien polypeptidisidosten muodostukseen.

Edellä esitettyyn nojaten voidaan siis olettaa että välttämättömien aminohappojen puute ja glukoosin puute voivat rajoittaa maitovalkuaisen synteesiä ja näin myös vaikuttaa maidon valkuaispitoisuuteen. Tutkimuksissa on todettu että aminohappo-glutamiinihappo toimii glukogeenisena aineena lehmän elimistössä, ja siitä tarpeen tullen muodostuu glukoosia. Ei-välttämättömistä aminohapoisța voi myös muodostua rajoitetussa määrin rasvahappoja maitorauhasessa.

Maidon valkuaispitoisuutta ei juuri voida ruokinnallisin keinoin kohottaa sellaisella lehmällä, jota on ruokittu normien mukaisesti. Lievä positiivinen vaikutus valkuaisprosenttiin on saatu lisäämälla propioni- tai maitohappoa suoraan pötsiin tai rehuannokseen. Myös kohtuullisella raakavalkuais- ja energialisäyksellä voidaan maidon valkuaispitoisuutta hiukan lisätä.

Maitovalkuaisprosentti laskee pidettäessä lehmää energia-aliruokinnalla tai pitempiaikaisella proteiinivajauksella.

Runsaanlainen NPN-typen käyttö lisää maidon NPN-fraktion määrää. Mikäli lehmän ravinnon luonnollinen typpimäärä on normeihin nähden liian alhainen voidaan NPN-lisäyksellä kohottaa myös maidon valkuaispitoisuutta. Ravitsemuksellisessa mielessä maidon valkuainen on varsin arvokasta.

\section{Sokeri}

Maidossa pääasiallinen sokeri on laktoosi, joka on muodostunut galaktoosista ja glukoosista. Tutkimuksissa on todettu että laktoosi muodostuu maitorauhasen verestä ottamasta glukoosista. Maidon sokeripitoisuuden ollessa $4.8 \%$ tarvitaan yhden maitolitran sisältämän laktoosin muodostusta varten veressä $50 \mathrm{~g}$ glukoosia. Pötsissä muodostuvista haihtuvista ravahapoista propionihappo on tärkein glukoosin esiaine. Propionihappo muutetaan maksassa glukoosiksi, josta se lähtee vereen tarpeen tullen.

Glukoosin kysyntä on erittäin suuri runsaan tuotannon aikana, koska sitä käytetään myös energian tarpeen tyydyttämiseen maitorauhasessa (noin 15- 
$41 \%$ veriseerumista otetusta glukoosista hapettuu $\left.\mathrm{CO}_{2}: \mathrm{ksi}\right)$. Tosin märehtijöillä on kyky käyttää myös etikkahappoa tähän tarkoitukseen.

Antamalla lehmälle sokeria ei tämä sokeri imeydy sellaisenaan vereen vaan se hajaantuu nopeasti pötsissä. Runsaalla väkirehuruokinnallakaan ei pötsistä pääse lävitse kuin vähäisiä määriä sellaisia aineksia, jotka ohutsuolessa hajaantumisen kautta voivat vapauttaa yksinkertaisia sokereita vereen imeytymistä varten.

Jos lehmän veren glukoosipitoisuus vaihtelee $40-80 \mathrm{mg} \%$ ei maidon sokeripitoisuuteen voida juuri ruokinnalla vaikuttaa. Silloin kun veren sokerimäärä on normaalia alempi eli alle $40 \mathrm{mg} \%$ voidaan glukogeenisiä rehuja syöttämällä (esim. jauhot, juurikkaat, maissihiutaleet, propylenglykoli, glyseroli, propionihappo jne.) kohottaa maidon laktoosipitoisuutta.

\section{Kivennäisaineet}

Rehuannoksen kalsium- ja fosforipitoisuudet eivät sanottavasti vaikuta maidon pitoisuuksiin. Jos näitä kivennäisiä ei ole riittävästi tarjolla, niin tuotos mielummin alenee kuin kivennäispitoisuus muuttuu. Magnesium vaikuttaa mieluummin maidon muihin aineosiin kuin maidon magnesiumpitoisuuteen. Maidon natrium-, kloori- ja kaliumpitoisuuksia säädellään mm. osmoottisen paineen avulla: jos maitosokerin määrä maidossa alenee niin vm. kivennäisten varsinkin natriumin ja kloorin määrät nousevat.

Maidon rautapitoisuuteen ei juuri voida vaikuttaa. Kuparipitoisuutta voidaan nostaa hiukan antamalla runsaammin kuparia lehmälle. Sinkin, mangaanin, koboltin ja seleenin määriä voidaan lisätä useampikertaiseksi konsetraatioksi ruokinnalla jos lehmällä on puutetța näistä kivennäisistä. Jodin määrää voidaan lisätä jopa satakertaiseksi ruokinnalla.

Maidossa voi olla joskus haitallisia mineraaleja. Näistä esim. lyijyn määrää voidaan vaikuttaa ruokinnalla. Antamalla kivennäisiä lehmälle siinä mielessä että maidon kivennäis- ja hivenaineravintoarvoa voitaisiin lisätä ei liene mainittavaa merkitystä muiden kuin jodin kohdalla.

\section{Vitamiinit}

Vitamiinit kulkeutuvat verestä maitoon sellaisenaan. Rasvaliukoiset vitamiinit esiintyvät maidossa rasvojen yhteydessä. Rasvaliukoisten vitamiinien määrää voidaan lisätä maidossa ruokinnallisin keinoin. Maidossa on sekä A-vitamiinia että tämän vitamiinin esiainetta karotiinia. Näiden yhteismäärä kuvastaa maidon A-vitamiiniaktiviteettia. Tätä aktiviteettia voidaan nostaa antamalla lehmälle kesällä laidunta ja talvella ruohosta tai naateista valmistettua säilörehua tai A-vitamiinivalmisteita. Laidunkautena lehmän maksaan kertyy vitamiinivarasto, joka riittää moneksi kuukaudeksi talvikautena tyydyțämään lehmän tarpeet ja jopa ylläpitämään maidon A-vitamiiniaktiviteettiakin suhteellisen korkeana. Talvimaidossa on silti yleensä vähemmän Avitamiinia kuin kesämaidossa. 
D-vitamiinin määrää maidossa voidaan säädellä antamalla lehmälle Dvitamiinipitoisia, auringossa kuivațtuja heiniä tai D-vitamiinivalmisteita. Lehmien ollessa kesällä ulkona auringon paisteessa niiden elimistössä syntetisoituu runsaasti D-vitamiinia. Tällöin myös maidon D-vitamiinipitoisuus on korkeampi kuin talvella.

Maidossa on kesällä enemmän E-vitamiinia (tokoferolia) kuin talvella. Ruohot sisältävät runsaasti ja viljat kohtalaisen runsaasti tokoferolia.

Päätelmänä rasvaliukoisten vitamiinien kohdalla voidaan sanoa, että niiden määrää voidaan maidossa nostaa ruokinnallisin keinoin, mutta hyötysuhde on kokolailla heikko.

Vesiliukoisista vitamiineista B-ryhmän vitamiinit syntetisoidaan pötsissä mikrobien toimesta. Koboltin puutteessa $B_{12}$-vitamiinin synteesi saattaa jäädä liian pieneksi. Pötsisynteesi on normaaliruokinnalla yleensä riittävää sekä lehmän tarpeisiin että maidon vitamiinipitoisuuden ylläpitämiseen. Maidon B-vitamiinipitoisuutta voidaan lisätä syöttämällä lehmälle suuria B-vitamiiniannoksia. Hyötysuhde on kuitenkin varsin heikko. B-vitamiinien syöttö lehmille on taloudellisessa mielessä kannattamatonta maidon B-vitamiinitason nostamiseksi.

Maidon C-vitamiinipitoisuus on suhteellisen muuttumaton eikä siihenkään juuri voida ruokinnalla vaikuttaa.

\section{KIRJALLISUUTTA}

Ammerman, C. B., Chicco, C. F., Moore, J. E., van Walleghem, P. A. \& Arrington, L. R. 1971. Effect of dietary magnesium on voluntary feed intake and rumen fermentations. J. Dairy Sci. 54: 1288.

AntilA, P. 1973. Occurrence of certain trace-elements in cow's milk. Meijeritiet. Aikak. 32, 2: $1-142$.

Armstrong, D. G. \& Prescotr, J. H. D. 1971. Amount, physical form and composition of feed and milk secretion in the dairy cow. In book: Lactation ed. R. Falconer, London p. $349-375$.

Bauman, D. E., Davis, C. L. \& Bucholtz, H. F. 1971. Propionate production in the rumen of cows fed either a control or high-grain, low-fiber diet. J. Dairy Sci. 54: 1282.

Bishop, R. B. 1971. Methionine hydroxy analogue supplementation in beef and dairy cattle. Feedstuffs, Jan. 30 , p. 31.

Brown, R. E. 1971. The conversion of nutrients into milk. Proc. 3rd Nutr. Confer. Feed Manufact. Ed. H. Swan \& D. Lewis. p. 23-35.

Chalmers, M. I. 1971. Nitrogen nutrition for lactation. In book: Lactation, ed. R. Falconer, London, p. 379-391.

Decaen, C. \& Ghadaki, M. B. 1970. Variation de la sécrétion des acides des matières grasses du lait de vache a la mise a l'herbe et au cours des six premierès semaines d'exploitation du fourrage vert. Ann. Zootechn. 19:399-411.

Emery, R. S. 1973. Biosynthesis of milk fat. J. Dairy Sci. 56: 1187.

FARrell, H. M., Jr. 1973. Models for casein micelle formation. J. Dairy Sci. 56: 1195.

GREGORY, M. E. 1967. Reviews of the progress of dairy science. Sect. D. Nutritive value of milk and milk products. Watersoluble vitamins in milk and milk products. J. Dairy Res. 34: 169.

KiermeIer, F. \& RenNer, E. 1966. Dairy research in Germany 1960-65. D. S. A. 28: $331-$ 349. 
Kirchgessner, M., Friesecke, H. \& КосH, G. 1965. Fütterung und Milchzusammensetzung. 292 p., Wien.

Kronfeld, D. S. 1973. A lack of dietary fat relative to glucose precursors may cause ketosis or depress milk fat content. In book: Production disease in farm animals, ed. J. M. Payne, K. G. Hibbitt \& B. F. Sansom. p. 230-237.

Rémond, B., Champredon, C., Decaen, C., Pion, R. \& Journet, M. 1971. Influence d'un apport de DL-méthionine a des vaches au début de la lactation sur la production laitière et la composition du sang. Ann. Biol. anim. Bioch. Biophys. 11: 455-469.

Roок, I. A. F. \& WheеLock, J. V. 1967. Reviews of the progress of dairy science. Sect. C. Dairy chemistry. The secretion of water and of water-soluble constituents in milk. J. Dairy Res. 34: 273.

SAARINEN, P. 1957. The quality of animal products in relation to the nutrition of farm livestock. VIIth Intern. congr. Anim. Husbandry, Madrid 64 p.

Thompson, S. Y. 1968. Reviews of the progress of dairy science. Section D. Nutritive value of milk and milk products. Fat soluble vitamins in milk and milk products. J. Dairy Res. 35: 149.

Tremere, A. E., Merrill, W. G. \& Loosli, J. K. 1967. Effects of pelleting concentrate mixtures of varying starch content on milk yield an compsition. J. Dairy Sci. 50: 1606.

Underwood, E. J. 1971. Trace elements in human and animal nutrition. 3rd. ed. New York $\mathrm{XIII}+543 \mathrm{p}$.

Walleghem, P. A. \& Arrington, L. R. 1971. Effect of dietary magnesium on voluntary feed intake and rumen fermentations. J. Dairy Sci. 54: 1288.

Yamdagni, S., Warner, R. G. \& Loosli, J. K. 1967. Effects of pelleting concentrate mixtures of varying starch content on milk yield and composition. J. Dairy Sci. 50: 1606. 